\title{
Obituaries
}

JOSHUA O. LEIBOWITZ

(1895-1993)

The passing of Joshua Leibowitz on 10 July 1993 closed a long and distinguished chapter in the history of medicine. His particular blend of medical, linguistic and historical scholarship was representative of that Baltic-Jewish tradition of learning which contributed so much to European culture before its dispersal and decimation by the Nazi horror. He will be widely mourned by the history of medicine community.

His particular association with the Wellcome Institute was close and affectionate. He and his wife Hannah spent a number of extended study periods in London during the 1960s and 70s and became keenly interested in the development of the Institute and its Library. At the opening of the then new Oriental Reading Room he characteristically insisted on intoning some appropriate verses from the Hebrew scriptures- "to get it off to a good start". Never the austere "Herr Professor Doktor" but always instinctively a teacher, he endeared himself to staff by his willingness to discuss and debate all manner of historical and cultural topics. His learning inspired awe, and his complete lack of academic condescension, affection.

He was born in 1895 in Vilna (now Vilnius, but at that period part of Russia), but spent his school years in Riga. In 1913 he began his medical studies at the University of Heidelberg, but these were soon interrupted by the world war. Internment followed, but his wider studies continued, particularly in the Hebrew language. In 1918 he was able to resume medical studies, receiving his MD degree in 1922. Medical training at Heidelberg was made to accommodate courses on philosophy and the history of art as well as rabbinical learning.

Joshua Leibowitz's medical interests ranged through internal medicine, psychiatry and, particularly, neurology. His years as Director of the Jewish Sanatorium in Bad-Homberg brought him into fruitful contact with the intellectual riches of the then flourishing Jewish community of Frankfurt-am-Main, where he taught Hebrew literature and Jewish thought at the Judisches Lehrhaus. He was already accumulating interests and book collections in the history of medicine: building a choice rare book library which was to travel with him to Palestine in 1935. He was co-founder of the Israel Society for the History of Medicine and Science in 1947 and of the journal Koroth in 1952. In 1957 he began the first formal course of instruction in the history of medicine at the Hebrew University, Hadassah Medical School. As a pillar of the International Society for the History of Medicine he attended all its international congresses between 1950 and 1982, delighting in opportunities to meet colleagues and extend his own work.

Professor Leibowitz was intellectually active until well after his ninety-fifth year, publishing his last paper in Koroth (with J. Urbach) in 1991. His bibliography in medical history was long and distinguished, but he is likely to be remembered chiefly for his monograph on The history of coronary heart disease in 1970. (A bibliography of his work between 1933 and 1984 was published by David Wilk in Koroth, 1985, 8, No. 11-12).

Professor Leibowitz leaves behind his wife and devoted companion Hannah. Their inseparability, and her gracious personality, ensure that our condolences are heartfelt.

Eric J. Freeman

(Note: I am grateful to Professor Samuel S. Kottek, Faculty of Medicine, Hebrew University, for his kind permission to make free use of his tribute to Professor Leibowitz, published in Koroth in 1985, together with additional private communications.)

\section{SIDNEY HERBERT WATKINS}

(1912-1993)

Sidney Watkins, who died aged 81 on 24 August 1993, worked as an assistant in the Wellcome Library from 1946 to 1977. He was the protégé of William Bishop, Wellcome Librarian (and later 